\title{
ULTRASOUND ASSISTED PROCESS FOR ENHANCED INTERLAMINAR SHEAR STRENGTH OF CARBON FIBER/EPOXY RESIN COMPOSITES
}

\author{
Gordana Bogoeva-Gaceva ${ }^{1 *}$, Niko Heraković², Dimko Dimeski ${ }^{3}$, Viktor Stefov ${ }^{4}$ \\ ${ }^{1}$ Ss. Cyril and Methodius University, Faculty of Technology and Metallurgy, Skopje, \\ Republic of Macedonia \\ ${ }^{2}$ University in Ljubljana, Faculty of Mechanical Engineering, Ljubljana, Slovenia \\ ${ }^{3}$ Goce Delčev University, Štip, Republic of Macedonia \\ ${ }^{4}$ Ss. Cyril and Methodius University, Faculty of Natural Sciences and Mathematics, \\ Institute of Chemistry, Skopje, Republic of Macedonia \\ gordana@tmf.ukim.edu.mk
}

\begin{abstract}
The influence of ultrasonic treatment, applied during the impregnation of carbon fiber bundle by resin system, on interface sensitive properties of carbon fiber/epoxy resin composites has been analyzed. The formation of the network has been followed on model composites containing untreated, oxidized and epoxy sized fibers by Fourier transform infrared microscopy (FTIR-microscopy) and differential scanning calorimetry (DSC). The enhanced interlaminar shear strength (ILSS), found for the composites treated by ultrasound, is attributed to the formation of more homogeneous and dense network, which is especially pronounced for epoxy sized carbon fiber composites.
\end{abstract}

Key words: carbon fibers; epoxy composites; interlaminar shear strength; ultrasound treatment

\author{
ПРИМЕНА НА УЛТРАЗВУК ВО ПРОЦЕС НА ДОБИВАЊЕ \\ ЕПОКСИДНИ КОМПОЗИТИ СО ЈАГЛЕРОДНИ ВЛАКНА ЗА ЗГОЛЕМУВАњЕ \\ НА НИВНАТА МЕЃУСЛОЈНА ЈАЧИНА НА СМОЛКНУВАЫЕ
}

\begin{abstract}
Испитувано е влијанието на ултразвучниот третман, применет во фазата на импрегнација на јаглеродни влакна со епоксидна смола, врз својствата на епокси-композити кои се чувствителни на меѓуфазната област влакно/полимерна матрица. Формирањето на вмрежената структура кај полимерот е следено врз моделни композити коишто се зајакнати со нетретирани, оксидирани и епокси-третирани јаглеродни влакна со примена на инфрацрвена (FTIR) микроскопија и диференцијална скенирачка калориметрија (DSC). Се смета дека зголемената меѓуслојна јачина на смолкнување кај композитите подложени на ултразвучен третман е резултат на похомогената структура со повисок степен на вмрежување на епоксидната смола, ефект којшто е особено изразен кај композитите на база на јаглеродни влакна со епоксиден премаз врз површината.
\end{abstract}

Клучни зборови: епоксидни композити; меѓуслојна јачина на смолкнување; ултразвучен третман 


\section{INTRODUCTION}

The interface between the carbon fiber and resin matrix plays a critical role in controlling the overall properties of the composites. Fracture toughness, off-axis strength, inter-laminar shear strength (ILSS) and other mechanical properties depend strongly on the interfacial adhesion, due to the fact that the load stress is transferred through the fiber/matrix interface. In fact, reinforcing fibers generally have coatings or sizing designed to protect the fiber from damage during processing, and also to compatibilize their surface with the intended matrix. Oxidative etching, electrochemical methods, polymer coating and plasma activation are commonly used treatments to increase the interfacial bonding between carbon fibers and resin by introducing chemical groups on carbon fibers surface and increase of their surface free energy $[1,2]$.

Power ultrasound is widely applied in numerous industrial processes, since it is well known that it can enhance a variety of chemical and physical processes mainly due to the ultrasonic cavitation effect in a liquid medium $[3,4]$.

Recently it has been applied to improve the interface properties of aramid/epoxy composites, and the enhanced interlaminar shear strength has been attributed to the ultrasonic cavitation which improves the wetting between aramid fibers and resin $[5,6]$.

A new ultrasound (15-1000 kHz) assisted melt extrusion process was developed and patented for manufacturing of PEI/MWNT and other polymer nanocomposites. The ultrasonically treated nanocomposites show significant change in the rheological behavior with tremendous increase in the viscosity, storage modulus and reduced damping characteristics as compared to the untreated ones indicating the better dispersion of nanotubes [7].

Our previous studies of different carbon fiber/epoxy systems have evaluated the influence of the fiber surface chemistry related to the cure kinetics of amine- and anhydride curing systems. [8]. It was found that the influence of the surface chemistry is related to the earlier stages of cure, and the final crosslinking degree of the network is not strongly affected by the progress of the reaction at the interface $[8,9]$. Comparing the results obtained for anhydride and amine-curing systems reinforced with the same type of carbon fibers, it was demonstrated that the higher value of epoxy consumption in the interphase region (determined by FTIR-microscopy) of epoxy-sized carbon fibers is responsible for increased interface crosslink density as compared to unsized, oxidized and plasma treated fibers containing composites $[10,11]$. As a result of the creation of an interface region with different rheological and mechanical properties where the epoxy-treated and oxidized fibers meet, some differences in the stiffness and the response to impact of the bulk composites were found [10-14].

In this first part of our paper we investigate the influence of ultrasonic treatment applied to the fiber bundle after impregnation by epoxy resin on mechanical properties of the composites reinforced with untreated unsized, oxidized and epoxy-sized carbon fibers.

\section{EXPERIMENTAL}

Carbon fibers with a nominal diameter of $7 \mu \mathrm{m}$ (Teijin Fibers Ltd.), oxidized (CFO), epoxy sized (CFE) and untreated unsized (CF) have been used to investigate the influence of ultrasound treatment on mechanical properties of epoxy resin composites. To exclude the effect of fiber surface morphology on interface sensitive properties, CFO fibers without any pronounced roughening of the surface within the resolution range of the $\operatorname{SEM}(0.1 \mu \mathrm{m})$ were chosen for the production of epoxy composites.

Commercial grade bifunctional epoxy resin with an anhydride of phtalic acid as a hardener and dimethylaniline as accelerator were used to prepare unidirectional composites with $60 \%$ vol carbon fibers by impregnation and hot pressing procedure. The curing of the resin was carried out at $80{ }^{\circ} \mathrm{C}$ for 1 hour and then post-cured at $140{ }^{\circ} \mathrm{C}$ for 2 hours. 
The ultrasound treatment (UST) was applied using ultrasound transducer with generator output frequency $20 \mathrm{kHz}$ and power $225 \mathrm{~W}$, at total time of treatment of $2 \mathrm{~min}$. The transducer was applied directly to the continuous moving impregnated carbon fiber bundle by epoxy resin system, with moving speed of $0.7 \mathrm{~m} \cdot \mathrm{min}^{-1}$.

Fourier transform infra-red microscopy (FTIR-microscopy; Perkin-Elmer FTIR System 2000) was applied to characterize the progress of curing reaction in model composites that have undergone ultrasonic treatment during the impregnation of carbon fibers with epoxy resin. Previously described $\mathrm{KBr}$ technique $[8,9]$ allows determination of the degree of consumed epoxy groups in the course of isothermal curing at $120^{\circ} \mathrm{C}$. Epoxy consumption was determined on the basis of the $\mathrm{A}_{916} / \mathrm{A}_{1184}$ absorbance ratio, where the $916 \mathrm{~cm}^{-1}$ band is characteristic of the epoxy group and the $1184 \mathrm{~cm}^{-1}$ band corresponds to the C-C stretching mode of the bridge carbon atom between two $p$-phenylene groups. A deconvolution program (subroutines of PC programs: GRAMS/386 ver. 2.02 and LABCALC Ver. C2.22, developed by Galactic Industries Company, USA) was used to resolve the overlapping bands with a curve-fitting procedure previously applied.

Differential scanning calorimetry (DSC) was performed with a Perkin-Elmer DSC-7 under nitrogen atmosphere at a heating rate of 10 $\mathrm{K} \cdot \mathrm{min}^{-1}$ to determine the progress of the cure of epoxy-impregnated fiber bundles (representing model composites). The enthalpy of cure $(\Delta H)$ and peak temperature $\left(T_{p}\right)$ were determined from this first heating (curing) run. The first heating run was followed by rapid cooling and a second heating run was made on the same sample to obtain the glass transition temperature $\left(T_{g}\right)$ of the network.

Contact angle measurements were performed using the static-droplet-on-a-single-fiber method, as described elsewhere [13]. To provide a representative value of contact angle, values from 35-40 replicate specimens from each sample (fiber/epoxy resin droplet) were averaged.

Viscosity measurements were carried out by falling ball method, according to DIN 53015 .
Interlaminar shear strength (ILSS) of the composites was determined by standard shortbeam shear test at crosshead speed of $1 \mathrm{~mm} \cdot \mathrm{min}^{-1}$.

\section{RESULTS AND DISCUSSION}

Among the factors responsible for the properties of the composites is the chemical structure of the network which, in turn, is influenced by the reactions that occur during the curing process in the polymer matrix, as well as in the fiber/matrix interphase.

The epoxy resins are multicomponent systems, containing epoxide, hardener, accelerators, diluents and often - plasticizers. The initial uncured state is characterized by a low viscosity, allowing flow and interpenetration of the matrix into the reinforcing fiber bundles. However, the phenomena of redistribution of the resin components in the vicinity of the surface make the investigation of the interphase zone difficult, especially before the vitrification occurs. In our previous studies, Fourier transform infrared microscopy (FTIR-microscopy) was successfully applied to characterize the curing reaction at the interphase of carbon fibers, by using $\mathrm{KBr}$ technique [10].

The kinetics of the curing process in model composites, representing the carbon fiber bundle wetted by epoxy matrix in US-assisted process was followed by FTIR-microscopy, applying the procedure for determination of epoxy consumption on the basis of the $\mathrm{A}_{916} / \mathrm{A}_{1184}$ absorbance ratio described earlier [9]. The results are presented in Figure 1, Figure 2 and Table 1.

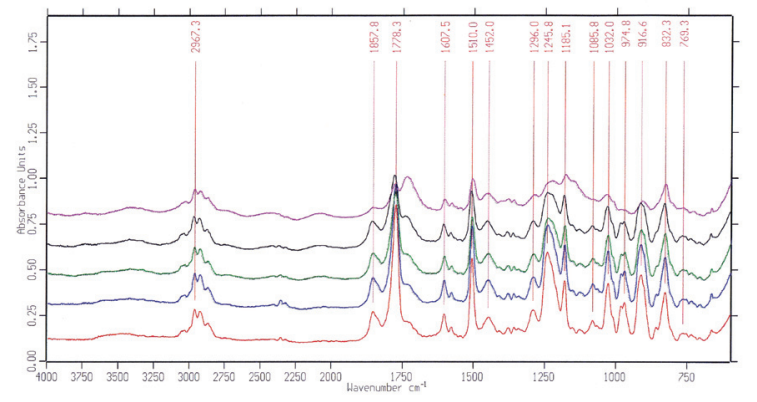

Fig. 1. FTIR-microscopy spectra of epoxy resin registered during the progress of the curing process: bottom-up rising of the temperature from $25^{\circ} \mathrm{C}$ to $120^{\circ} \mathrm{C}\left(25^{\circ} \mathrm{C} ; 45^{\circ} \mathrm{C} ; 80{ }^{\circ} \mathrm{C} ; 100{ }^{\circ} \mathrm{C}\right.$ and $\left.120^{\circ} \mathrm{C}\right)$ 
Figure 1 represents FTIR-microscopy spectra of epoxy resin registered during the progress of the curing process at temperature $25^{\circ} \mathrm{C}$, $45^{\circ} \mathrm{C}, 80^{\circ} \mathrm{C}, 100^{\circ} \mathrm{C}$ and $120^{\circ} \mathrm{C}$. Based on these preliminary results obtained for nonisothermal curing, the temperature of $120^{\circ} \mathrm{C}$ for isothermal process was chosen to follow the cure kinetics in order to provide more comprehensive data on the influence of the ultrasonic treatment on the state of the network (see Figure 2).
In anhydride epoxy systems the main reaction taking place during curing is the reaction between the anhydride group of the hardener and the epoxy group of the resin, allowing evaluation of the cure kinetics by following the epoxy group consumption $[8,9]$.

The effect of ultrasonic treatment on the epoxy consumption during isothermal curing is especially seen for model composites containing sized carbon fibers, as seen from Table 1.

Table 1

Epoxy consumption rate (\%) determined by FTIR-microscopy for model composites containing oxidized (CFO), epoxy sized (CFE) and untreated (CF) carbon fibers: conventional and ultrasound assisted procedure (ultrasound)

\begin{tabular}{ccccccc}
\hline \hline$t /$ min & CFU & $\begin{array}{c}\text { CFU } \\
\text { (ultrasound) }\end{array}$ & CFO & $\begin{array}{c}\text { CFO } \\
\text { (ultrasound) }\end{array}$ & CFE & $\begin{array}{c}\text { CFE } \\
\text { (ultrasound) }\end{array}$ \\
\hline 6 & 45 & - & 48 & 50 & 50 & 58 \\
10 & 57 & 60 & 62 & 60 & 63 & 75 \\
15 & 70 & - & 75 & 78 & 78 & 84 \\
20 & 82 & 81 & 84 & 85 & 85 & 91 \\
30 & 85 & 82 & 88 & 89 & 90 & 94 \\
40 & 85 & 82 & 88 & 90 & 91 & 96 \\
60 & 85 & - & 90 & 90 & 93 & 96 \\
\hline \hline
\end{tabular}

Obviously, higher degree of crosslinking is reached especially at early stages of the process. Thus, after $10 \mathrm{~min}$, epoxy consumption of even $75 \%$ is determined for the system treated ultrasonically, as compared to 63 $\%$ for the untreated one. Also, the final degree of crosslinking after $60 \mathrm{~min}$ is the highest for model composites with epoxy sized fibers that have undergone ultrasound treatment. Insignificant changes are found for oxidized carbon fibers, while the ultrasound assisted procedure has no influence on the final epoxy consumption rate in a system with untreated fibers.

These results are in accordance with our earlier findings that at an early stage of cure (30

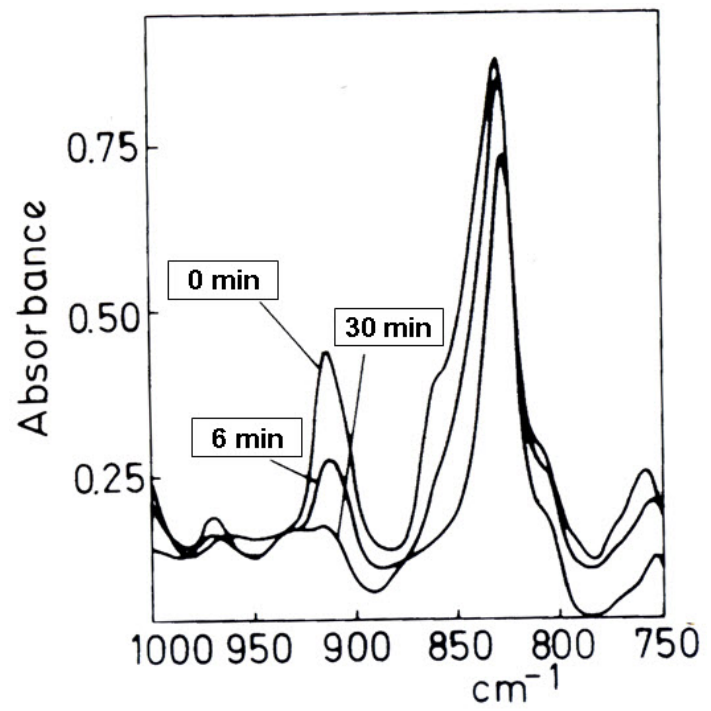

Fig. 2. Changes of the $916 \mathrm{~cm}^{-1}$ epoxy band profile with curing time (0-30 $\mathrm{min})$ at $T=120^{\circ} \mathrm{C}$ followed by FTIR-microscopy 
min) the presence of fibers with different surface chemistry influences the crosslink density of the network, due to the possible catalytic activity of certain functional groups at the surface and also to the phenomenon of preferable absorption of some components of the epoxy resin [11].

The results of DSC experiments with model composites are presented in Table 2.
Similar values for the reaction peak temperature, only slightly affected (shifted towards lower values) by the ultrasound treatment, are found for oxidized- and epoxy-sized fibers-containing systems. However, the heat of cure determined from the reaction exotherm is higher for the system with epoxy-sized fibers.

Ta b 1 e 2

DSC data for model composites (fiber volume fraction 0.6) cured in situ during the DSC measurements (assignation as in Table 1): values in brackets represent the results obtained for ultrasound assisted procedure applied for model composites

\begin{tabular}{ccccccc}
\hline \hline Fiber & $\Delta H / \mathrm{J} \mathrm{g}^{-1}$ & $\mathrm{CV}^{*} / \%$ & $T_{p} /{ }^{\circ} \mathrm{C}$ & $\mathrm{CV} / \%$ & $T_{g} /{ }^{\circ} \mathrm{C}$ & $\mathrm{CV} / \%$ \\
\hline CFO & $123.2(123.0)$ & 1.1 & $144.7(144.5)$ & 0.8 & $142.0(143.0)$ & 0.3 \\
CFE & $170.4(172.0)$ & 1.2 & $141.2(141.0)$ & 1.0 & $136.0(143.0)$ & 0.5 \\
\hline \hline
\end{tabular}

The most impressive result, clearly confirming the influence of ultrasound treatment is seen from the determined glass transition temperature of the network formed, which is directly related to its overall crosslink density. Although the $T_{g}$ of CFE-composites $\left(136^{\circ} \mathrm{C}\right)$ produced via conventional procedure is lower than the one for CFO-composites $\left(142^{\circ} \mathrm{C}\right)$, the $T_{g}$-values for these systems are the same (143 $\left.{ }^{\circ} \stackrel{g}{\mathrm{C}}\right)$ after the ultrasound treatment. It has been shown that ultrasonic treatment can significantly decrease the viscosity and surface tension of the resin system, thus increasing the wettability, and also the oxygen content of the fiber surface due to the ultrasonic cavitation effects [15]. However, the ultrasound treatment applied in our experiments caused the reduction of the viscosity of only several percents (from $32 \mathrm{mN} \cdot \mathrm{m}^{-1}$ to $30.5 \mathrm{mN} \cdot \mathrm{m}^{-1}$ ). Bearing this in mind and based on our DSC results, it could be assumed that ultrasound treatment has stimulated favorable conditions of dissolution of the fiber's epoxide sizing into the matrix, enhancing the interfacial bonding strength, and this way - creation of more uniform network with dense crosslink structure.

The penetration rate of the resin into the fiber bundle depends on the surface free energy of the resin and the fiber, and is governed by other factors as well. The results of the liquid droplet contact angle measurements have revealed similar values for fiber/epoxy contact angle of 57 degrees and 56 degrees, for CFO and CFE, respectively, while the contact angle for CFU is 75 degrees. Evidently, much better wettability is expected for CFE and CFO fibers.

Table 3 shows the results obtained for ILSS of the composites produced by hot pressing after via ultrasound assisted process of impregnation. 
Table 3

ILSS of the composites containing epoxy sized (CFE), oxidized (CFO) and untreated

(CFU) carbon fibers (fiber volume fraction 0.6) produced by conventional and ultrasound assisted procedure (values in brackets)

\begin{tabular}{ccccc}
\hline \hline Fiber & ILSS / MPa & $\Delta$ ILSS $/ \%$ & S.D. $^{*}$ & CV /\% \\
\hline CFE & $58(67)$ & 15 & $1.8(1.4)$ & $2.7(2.1)$ \\
CFO & $67(75)$ & 12 & $2.1(2.0)$ & $2.9(2.4)$ \\
CFU & $35(38)$ & 8.6 & $3.9(2.8)$ & $4.1(4.0)$ \\
\hline \hline
\end{tabular}

*Standard deviation

ILSS is increased for all of investigated composites, although the most positive effect of the treatment is seen for epoxy sized carbon fiber composites. It should be mentioned that the values of standard deviation and coefficient of variation are also decreased by the treatment. Having in mind the results obtained by FTIRmicroscopy and DSC analysis, the increment of ILSS value due to ultrasonic treatment can be attributed to the enhanced interfacial interactions and improved wetting of fibers by epoxy resin. Ultrasonic cavitation $[16,17]$ generated during the treatment is likely to force epoxy resin into the fiber bundle thus increasing additionally the overall interfibrillar adhesion. Obviously, higher degree of epoxy consumption, as well as higher $T_{g}$ of the network, determined for CFE containing composites, are a consequence of the increased molecular interactions at the interface, which in turn enhances the load transfer to the fiber.

Summarizing the results of our investigation, a conclusion could be derived that the ultrasound assisted process of impregnation of carbon fiber by epoxy resin, aimed for the production of epoxy resin composites, represent a promising technique for differently treated carbon fibers.

\section{CONCLUSION}

Ultrasonic treatment $(20 \mathrm{kHz} ; 225 \mathrm{~W} ; 2$ min) applied during the impregnation of carbon fibers with different surface chemistry by epoxy resin has resulted in drastically increased ILSS of the composites, produced by hot pressing. The formation of the network has been followed on model composites containing untreated, oxidized and epoxy sized fibers by FTIR-microscopy and DSC analysis. The enhanced ILSS (up to $15 \%$ ), found for the composites treated by ultrasound, is attributed to the formation of more homogeneous and dense network, as revealed by epoxy consumption rate and increased $T_{g}$, and this effect is especially pronounced for epoxy sized carbon fiber composites.

\section{REFERENCES}

[1] L. T. Drzal, Controlled Interphases in Composite Materials, In: Ishida H. (ed.) Elsevier Science, New York, 1990, pp. 309.

[2] M. Lewin and J. Preston, High Technology Fibers, Part A, Marcel Dekker Inc., New York, 1985, pp. 203-215.

[3] Y. T. Didenko, W. B. McNamara, K. S. Suslick, Hot spot conditions during cavitation in water, $\mathrm{J}$. Am. Chem. Soc., 121, 5817-5818 (1999).

[4] W. Lauterborn, Handbook of acoustics, In: Crocker M.J. (ed.), 1998, pp. 235-242. 
[5] L. Liu, Y. D. Huang, Z. Q. Zhang, Z. X. Jiang, L. N. Wu, Ultrasonic treatment of aramid fiber surface and its effect on the interface of aramid/epoxy composites, Appl. Surface Sci., 254, 2594-2599 (2008).

[6] L. Liu, Y. D. Huang, Z. Q. Zhang, Ultrasonic modification of aramid fiber/epoxy interface. J. Appl. Polym. Sci., 81, 2764-2768 (2001).

[7] A. Isayev, Ultrasound assisted continuous process for dispersion of nanofibers and nanotubes in polymers, USPC Class: 524495 (Patent Application No 20090275689)

[8] G. Bogoeva-Gaceva, E. Mäder, K. Sahre, Interphase characterization in epoxy resin/carbon fiber composites, Composite Interfaces, 4, 143-156 (1996).

[9] G. Bogoeva-Gaceva, A. Grozdanov, E. Mäder, The effect of interphase on kinetic peculiarities in model carbon fiber/epoxy composites studied by FTIR microscopy, Polimeri, 18, 215-221 (1997).

[10] G. Bogoeva-Gaceva, E. Mäder, L. Haüssler, A. Dekanski, Characterization of the surface and interphase of plasma-treated HM carbon fibers, Composites, Part A, 28 A, 445-452 (1997).

[11] G. Bogoeva-Gaceva, E. Mader, L. Haüssler, K. Sahre, Parameters affecting the interface properties in carbon fiber/epoxy systems, Composites, 26, 103-107 (1995).
[12] E. Mäder, K. Sahre, G. Bogoeva-Gaceva, Studying the interphase in epoxy resin/carbon fiber composites, Paper presented at $5^{\text {th }}$ Int. Conf. on Composite Interfaces (ICCI-V), Goteborg, June 1994.

[13] G. Bogoeva-Gaceva, D. Burevski, A. Janevski, The effect of surface treatment on the interfacial properties in carbon fiber/epoxy matrix composites, $J$. Mater. Sci., 30, 3543-3546 (1995).

[14] N. Dilsize, J.P. Wightman, Effect of acid-base properties of unsized and sized carbon fibers on fiber epoxy matrix adhesion, J. Colloids and Surfaces, 164, 325-336 (2000).

[15] Y. D. Huang, L. Liu, J. H. Qui, L. Shao, Influence of ultrasonic treatment on the characteristics of epoxy resin and the interfacial property of its carbon fiber composites, Comp. Sci. Technol., 62, 2153-2159 (2002).

[16] F. Burdin, N. A. Tsochatzidis, P. Guirand, A. M. Wilhelm, H. Delmas, Characterization of the acoustic cavitation cloud by two laser techniques, Ultrasonics Sonochemistry, 6, 43-51 (1999).

[17] J. Holtmannspötter, J. V. Czarnecki, H-J. Gudladt, The use of power ultrasound energy to support interface formation for structural adhesive bonding, Int. J. Adhes. Adhes., 30, 130-138 (2010). 